Meta

Journal des traducteurs

Translators' Journal

\title{
Exploring a New Narratological Paradigm for the Analysis of Narrative Communication in Translated Children's Literature
}

\section{Haidee Kruger}

Volume 56, numéro 4, décembre 2011

URI : https://id.erudit.org/iderudit/1011254ar

DOI : https://doi.org/10.7202/1011254ar

Aller au sommaire du numéro

\section{Éditeur(s)}

Les Presses de l’Université de Montréal

ISSN

0026-0452 (imprimé)

1492-1421 (numérique)

Découvrir la revue

Citer cet article

Kruger, H. (2011). Exploring a New Narratological Paradigm for the Analysis of Narrative Communication in Translated Children's Literature. Meta, 56(4), 812-832. https://doi.org/10.7202/1011254ar

\section{Résumé de l'article}

Dans sa tentative de rapprocher la traductologie et la narratologie, la recherche actuelle se fonde presque exclusivement sur la narratologie structuraliste, en partant du principe que les changements opérés à un niveau micro du texte auront pour résultat de modifier les différentes dimensions narratives du texte, et mèneront à une différente configuration de la situation de communication narrative dans les textes traduits par rapport aux textes source. Cependant, le présent article soutient les thèses suivantes : premièrement, que cette approche a pour résultat une conceptualisation de la situation de communication narrative de la traduction qui est particulièrement difficile à manipuler et qui le devient encore plus dans le contexte de traduction de la littérature enfantine ; deuxièmement, qu'elle ne prend pas suffisamment en compte le rôle (ou rôle potentiel) du lecteur ni celui du contexte, laissant ainsi ces deux aspects en dehors du processus d'analyse. Méthodologiquement parlant, cela signifie aussi que les écarts narratologiques en traduction sont identifiés la plupart du temps grâce à une analyse comparative qui, bien qu'elle soit utile, ne prend pas en considération l'acte naturel de lecture (dans lequel les lecteurs n'ont généralement pas accès au texte source). En revanche, l'article fait la présentation de la recherche préliminaire et exploratoire pour une base narratologique différente, qui inclut le lecteur en tant qu'élément constitutif. Cette base théorique, fondée sur les idées de Bortolussi et Dixon (2003), suggère une conception des éléments narratologiques en deux parties intimement liées : les caractéristiques textuelles et la construction du sens par le lecteur. L'article soutient qu'une telle base théorique fournit un moyen à la fois plus simple et plus sophistiqué de comprendre la communication narrative en ce qui concerne la littérature enfantine traduite. En effet, dans un premier temps, les caractéristiques textuelles des traductions et leurs originaux peuvent être analysés comparativement, ce qui pourrait révéler la présence du traducteur. Cependant, la deuxième dimension de la base théorique présentée ici soutient que malgré les changements opérés par les écarts dans la traduction dans les caractéristiques narratives, la réaction des lecteurs, quel que soit leur âge, aux textes pour enfants traduits, n'implique pas forcément que ceux-ci soient conscients de la « voix » du traducteur dans le texte. C'est là que cette base théorique se différencie des approches narratologiques standard de la communication narrative pour les textes traduits, dans la mesure où il suggère qu'il est nécessaire d'étudier non seulement les caractéristiques textuelles, mais également la construction du sens par le lecteur.
Ce document est protégé par la loi sur le droit d'auteur. L’utilisation des services d’Érudit (y compris la reproduction) est assujettie à sa politique d'utilisation que vous pouvez consulter en ligne.

https://apropos.erudit.org/fr/usagers/politique-dutilisation/ 


\title{
Exploring a New Narratological Paradigm for the Analysis of Narrative Communication in Translated Children's Literature
}

\author{
HAIDEE KRUGER \\ North-West University, Vanderbijlpark, South Africa \\ haidee.kruger@nwu.ac.za
}

\section{RÉSUMÉ}

Dans sa tentative de rapprocher la traductologie et la narratologie, la recherche actuelle se fonde presque exclusivement sur la narratologie structuraliste, en partant du principe que les changements opérés à un niveau micro du texte auront pour résultat de modifier les différentes dimensions narratives du texte, et mèneront à une différente configuration de la situation de communication narrative dans les textes traduits par rapport aux textes source. Cependant, le présent article soutient les thèses suivantes: premièrement, que cette approche a pour résultat une conceptualisation de la situation de communication narrative de la traduction qui est particulièrement difficile à manipuler et qui le devient encore plus dans le contexte de traduction de la littérature enfantine; deuxièmement, qu'elle ne prend pas suffisamment en compte le rôle (ou rôle potentiel) du lecteur ni celui du contexte, laissant ainsi ces deux aspects en dehors du processus d'analyse. Méthodologiquement parlant, cela signifie aussi que les écarts narratologiques en traduction sont identifiés la plupart du temps grâce à une analyse comparative qui, bien qu'elle soit utile, ne prend pas en considération l'acte naturel de lecture (dans lequel les lecteurs n'ont généralement pas accès au texte source). En revanche, l'article fait la présentation de la recherche préliminaire et exploratoire pour une base narratologique différente, qui inclut le lecteur en tant qu'élément constitutif. Cette base théorique, fondée sur les idées de Bortolussi et Dixon (2003), suggère une conception des éléments narratologiques en deux parties intimement liées: les caractéristiques textuelles et la construction du sens par le lecteur. L'article soutient qu'une telle base théorique fournit un moyen à la fois plus simple et plus sophistiqué de comprendre la communication narrative en ce qui concerne la littérature enfantine traduite. En effet, dans un premier temps, les caractéristiques textuelles des traductions et leurs originaux peuvent être analysés comparativement, ce qui pourrait révéler la présence du traducteur. Cependant, la deuxième dimension de la base théorique présentée ici soutient que malgré les changements opérés par les écarts dans la traduction dans les caractéristiques narratives, la réaction des lecteurs, quel que soit leur âge, aux textes pour enfants traduits, n'implique pas forcément que ceux-ci soient conscients de la «voix» du traducteur dans le texte. C'est là que cette base théorique se différencie des approches narratologiques standard de la communication narrative pour les textes traduits, dans la mesure où il suggère qu'il est nécessaire d'étudier non seulement les caractéristiques textuelles, mais également la construction du sens par le lecteur.

\section{ABSTRACT}

Current contributions attempting to draw together translation studies and narratology are based almost exclusively on structuralist narratology, proceeding from the assumption that changes on the micro-level of the text will result in changes to the various narrative dimensions of the text, and will lead to a different configuration of the narrative communication situation in translated texts as compared to original works. However, it is argued in this paper that this approach, firstly, results in a conceptualisation of the 
narrative communication situation for the translated text that is particularly unwieldy and becomes even more so when considered in the context of translated children's literature. Secondly, this approach does not take adequate cognisance of the role (or potential role) of the reader and the context, leaving both these aspects largely outside the process of analysis. Methodologically, it also means that narratological shifts in translation are mostly identified by means of comparative analysis, which, while useful, leaves the natural reading situation (where readers do not usually have access to the source text) out of consideration. Instead, this paper presents a preliminary and exploratory investigation of an alternative narratological framework that includes the reader as a constitutive component. The framework, based on the ideas of Bortolussi and Dixon (2003), proposes a two-part, interlocked conception of narratological elements: textual features and reader constructions. It is argued that such a framework provides a simultaneously simpler and more sophisticated means of understanding narrative communication in translated children's literature. Firstly, translations and their source texts may be analysed comparatively in terms of their textual features, which may reveal the presence of the translator. However, the second dimension of the proposed framework posits that despite the fact that translation shifts effect changes in narrative features, child and adult readers' responses to translated children's texts do not necessarily and by default incorporate an awareness of the presence of an additional "voice" in the text, that of the translator. At this point the framework departs from standard narratological approaches to narrative communication in translated texts in proposing the necessity of investigating reader constructions rather than textual features alone.

\section{MOTS-CLÉS/KEYWORDS}

littérature enfantine, narratologie, caractéristiques textuelles, construction du sens, approches cognitives

children's literature, narratology, textual features, reader constructions, cognitive approaches

\section{Introduction: the directions of narratology}

The key question underlying this paper has to do with how one may conceptualise the effects of translation on the narrative communication situation as it relates to children's literature, ${ }^{1}$ particularly from within the theoretical paradigm of narratology. The disciplines of translation studies and narratology have, in the past two decades, had increasing acquaintance. However, an overview of salient contributions in the narratology/translation studies interface suggests that most of these have proceeded from an unproblematised classical narratological paradigm which discounts both context and reader (see section 2). Classical narratology, is, of course, deeply rooted in the structuralist paradigm, as exemplified in the work of (among others) Genette $(1980,1990)$. Its key project is to discover a universal narrative grammar or syntax, a deep structure of narrative generating all possible surface "utterances" of individual narrative texts. As such, it is a theory that lays unabashed claims to universality and objectivity. However, many of the central assumptions and projects of classical narratology have been eroded by, amongst other things, poststructuralism's questioning of the totalising and self-contained edifices of structuralism with its connotations of "binarisms, abstraction, logocentrism, ahistoricism, and untenable ideas of scientific objectivity" (Nünning 2003: 257). Brooke-Rose points out some of the consequences of this, explaining that structuralists' 
dream of a "science" of literature with universal rules had caused them to evacuate (a) the diachronic dimension, (b) traditional thematics, (c) interpretation, and (d) evaluation. Those were the tasks of "traditional" criticism and literary history, while the science of literature had the task of (1) discovering and describing how a narrative text functions, and (2) evolving a universal system. In practice, the scientific dream was quietly abandoned, and (a), (b), (c), and (d) have crept back. (Brooke-Rose 1990: 287-288)

This comment suggests some of the limitations of structuralist narratology, most crucially, in the context of this paper, its tendency to view the text synchronically, and as a closed and immanent structure to be analysed in scientific terms, an approach which discounts a number of diverse extratextual factors that interact with textual factors. These extratextual factors include matters such as context, history and temporality, meaning, interpretation and the role of the reader. Bal (1990: 736) condenses all these dimensions into her formulation of the central challenge to narratology as "the social embedding of narrative, or, in other words, its relationship to reality."

As a result of this inability to see, integrate or account for the varied social connections of narrative, many critics and theorists have dismissed structuralist narratology as an obsolete or at the very least unfashionable theory. Bal explains her view on the situation as follows:

Today's options seem to be either regression to earlier positions (Genette, 1983), primary focus on application, or rejection of narratology. All three are problematic: Regression demonstrates a powerlessness to move on; application may imply an unwarranted acceptation of imperfect theories; and rejection, while motivated by a shift in priorities, is also a denial of the importance of the questions - rather than the answers - of narratology, and sometimes even a lack of understanding. In general, more important issues, mainly historical and ideological ones, have taken priority... the concern for a reliable model for narrative analysis has more and more been put to the service of other concerns considered more vital for cultural studies. (Bal 1990: 728-729)

As a consequence, structuralist narratology has formed the foundation for various newer developments in narratology that, in various ways, attempt to adapt central narratological concepts in ways that are less totalising and more attuned to subjectivity in order to address some of the issues that are the blind spots of classical structuralist narratology. In this way, narratological tools may, in literary studies, be mobilised for diverse ends, not necessarily the construction of a narrative grammar. Similarly, narratology and narrative theory may be, and have been, utilised in various fields other than literary studies. Richardson (2000: 169) emphasises the increasing range and inclusiveness of narratological and narrative-based approaches in his comment that "[n]arrative... seems to be a kind of vortex around which other discourses orbit in ever closer proximity" (see also Nünning 2003). ${ }^{2}$

Based on this expansion and proliferation Herman (1999: 1) argues that structuralist narratology has evolved into a multiplicity of narratologies. Fludernik and Richardson (2000), Herman (1999), Nünning (2003) and Richardson (2000) list and outline some of these developments in narratology, including feminist and queer narratology, psychoanalytic narratology, poststructuralist narratology, cultural studies narratology, contextualist narratology, postcolonial narratology, constructivist narratology, cognitive narratology and postmodern narratology. While these approaches are profoundly heterogeneous, they 
all share the common conviction that narrative theory should not confine its attention to the texts themselves, but should also take account of their contexts, and that, at the same time, it should be developed further, moving on from structuralist analysis to a functional study of literature. (Kindt and Müller 2003: 207) ${ }^{3}$

In this sense, as Herman (1999: 8) emphasises, newer developments in narratology inevitably involve a focus that is both formal and functional, exploring the relationships between the textual and the contextual. Nünning (2003: 244-245) points out that these "postclassical narratologies" are thus interdisciplinary in nature, displaying an interest in the forms and functions of a wide range of narratives and in the dialogic negotiation of meanings, and focusing on issues such as context, culture, gender, history, interpretation, and the reading process - those aspects of narrative marginalised by structuralist narratology. However, it needs to be emphasised that these differences, for the most part, do not involve a focus on the aspects outlined here as opposed to a textual focus. Rather, textual and contextual issues are regarded as deeply intertwined. Finally, it also needs to be kept in mind that, as Fludernik (2003a: 331) remarks, traditional structuralist and linguistically oriented narratology continues to be practised and developed, with increasing theoretical sophistication.

One of the disciplines with which narratology has had several intersections is that of translation studies. However, it is argued in this paper that most of these intersections do not take cognisance of possibly valuable newer developments in narratology, and thus remain limited by their structuralist paradigm (see section 2). Focusing on the conceptualisation of the narrative communication situation, and particularly as it applies to translated children's literature, I argue that some of the more recent developments in narratology, particularly from within the contextualist and cognitive approach developed by Bortolussi and Dixon (2003), may offer useful supplementary and alternative conceptual and methodological tools for the analysis of narrative communication in translated children's literature (and possibly in translated literature generally).

\section{Existing research in narratology and translation studies}

Some notable contributions linking translation studies and narratology have been made by Bosseaux (2004, 2007), Hermans (1996), Kruger (2001, 2009), Levenston and Sonnenschein (1986), May (1994), O'Sullivan (2006), Schiavi (1996) and Van LeuvenZwart $(1989,1990)$. These contributions are broadly concerned with two aspects. The first aspect involves translation shifts, analysed in narratological terms. The second aspect revolves around the textual presence or absence of the translator as participant in the narrative communication situation. These two focuses are mostly combined, and existing research may be grouped into three categories, which appear to develop progressively:

- translation (shifts) analysed in terms of narratological concepts, but without attempting to correlate these shifts to the intratextual presence of the translator (although the norms governing the real translator's decision-making often form part of the focus of the argument) (e.g. Levenston and Sonnenschein 1986; May 1994; Van Leuven-Zwart 1989, 1990);

- arguments that either consciously argue (e.g. Hermans 1996; Schiavi 1996; O’Sullivan 2006) or explicitly assume (e.g. Bosseaux 2004, 2007) the case for the voice, presence 
and visibility of the translator in translations, and attempt to find textual traces of this presence, usually in translation shifts, but also in paratextual material such as translator's notes;

- arguments that proceed from a poststructuralist perspective and argue against the discursive presence of the translator as a separate and distinct presence in the text while simultaneously deconstructing basic narratological categories (e.g. Kruger 2001, 2009).

An investigation of these contributions suggests that (with the exception of Hermans 1996; Kruger 2001, 2009; May 1994), a structuralist or classical narratological paradigm is evident in most of the work. One example of this typical structuralist approach, that of Schiavi (1996), is discussed in the following section. The aim of this discussion is to provide an overview of a structuralist conceptualisation of the narrative-communication situation for translated texts, and to highlight some of the problems of the conventional structuralist approach in the context of translated children's literature.

\subsection{A structuralist conceptualisation of narrative communication in translated (children's) literature}

Schiavi (1996) refers to some of the work done on translation shifts, especially Van Leuven-Zwart's $(1989,1990)$ work from within the narratological paradigm, to develop her own argument. Her key premise is that translated texts cannot be analysed using (all) the same narratological categories as original texts, since translation means "that new entities enter a translated text, that they do not necessarily (or at least not completely) displace previously existing ones, but that they affect the whole structure" (Schiavi 1996: 2). In particular, she uses the idea of the shifts that take place in translation, and their effects on the macrotextual level, to argue for the acknowledgement of the existence of the translator's voice in the translation, a voice which "is in part standing in for the author's and in part autonomous. This voice creates a privileged relationship with the readers of translation, part mediational, part straightforward" (Schiavi 1996: 3). She points out that while the work of scholars like Van Leuven-Zwart $(1989,1990)$ hints at "presences" in a translated text, specifically the presence of the entity that is responsible for the "loss and gain" (Schiavi 1996: 4) of translation, this presence is never clearly delineated. Based on this, Schiavi proposes the following:

And since this "loss and gain" belongs to the translated text and is part of the new frame, there must be within the text the entity which brought it about. If we admit the presence of this entity it goes without saying that we are also forced to include its addressee which therefore must be called "addressee of the translation"... (Schiavi 1996: 4)

In attempting to describe this entity, Schiavi (1996) utilises and elaborates on the diagram of narrative communication outlined by Chatman (1978), presented here as Figure 1, and particularly the relationship between the narrator, the implied author and the implied reader. 
FIGURE 1

Model of narrative communication (adapted from Chatman 1978)

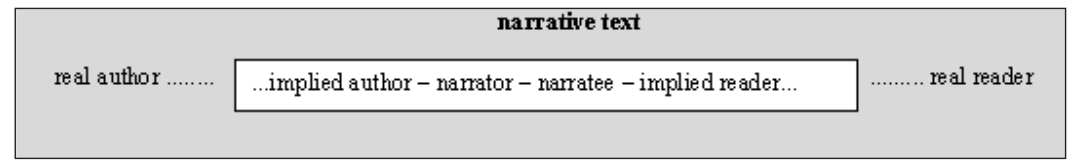

She argues that this same model cannot be applied indiscriminately to original as well as translated texts, since the narrator of the translated text cannot in a simple and straightforward manner be regarded as another textual element altered by translation (as assumed by, for example, May 1994), but should be viewed as standing in an integral relationship with another implied presence in the translation, which "informs" the narrator of the translation in the same way that the implied author "informs" the narrator of the original text. This implied presence she refers to as the "implied translator."

Schiavi (1996: 11) also points out that the immediate problem posed by translation for the conventional model of narrative communication is that the real reader of the original text is patently different to the real reader of the translation, and since there "is, and must be, a direct relationship" (Schiavi 1996: 11) between the real reader and the implied reader, the implied reader must therefore also be different. Hermans (1996: 28) argues along slightly different lines that translated narrative fiction addresses a different implied reader than the original, since the translation functions in a different context and "[a]ll texts are culturally embedded and require a frame of reference which is shared between sender and receiver to be able to function as vehicles for communication" (Hermans 1996: 28). Furthermore, since the real reader of the translation is different from the real reader of the original, she will also construct a different implied author, since this relationship is based on shared background knowledge and suppositions (Schiavi 1996: 12-13). This implied author of the translation is really a combination of the implied author of the source text, and the implied presence of the translator in the text. Ultimately, Schiavi points out that a

reader of translation will receive a sort of split message coming from two different addressers, both original although in two different senses: one originating from the author which is elaborated and mediated by the translator, and one (the language of the translation itself) originating directly from the translator. (Schiavi 1996: 14)

She then proposes a different communication model for translations, a model that is refined by O'Sullivan (2006: 103) and reproduced as Figure 2.

FIGURE 2

A model of narrative communication in translated texts (from O'Sullivan 2006: 103)

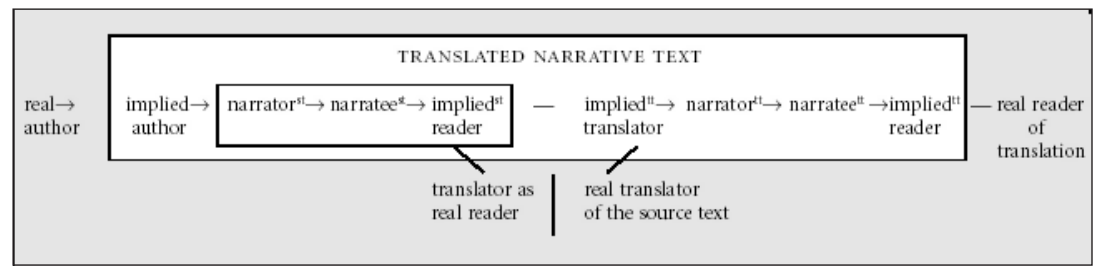


According to Schiavi (1996: 15), the box around the source-text narrator, narratee and implied reader suggests that the translator intercepts the function of these elements of the original text, interpreting the "standards, conventions, norms and narrative strategies" (Schiavi 1996: 15) embodied by the original implied author. From this position of interpretation, the real translator negotiates the production of a new text, intrinsically related to the original, but also re-processed for a different implied reader. As a consequence, the translation is marked by four new or mediated textual presences, that of

- the implied translator, who shares with

- the implied reader of the translation a set of assumptions regarding the target culture, and is reflected by

- the narrator of the translation, who has a corresponding

- narratee of the translation.

The narrator, narratee and implied reader of the source text are bracketed, and while they may remain present in latent form in the translation, they are subsumed in the reinterpretation process that results in the entities above. The implied author of the source text, however, remains outside of the interpretation process. This is meant to indicate that the original communication remains in some form, even though the translator's communication mediates, subtracts and adds (Schiavi 1996: 16). This, importantly, emphasises the presence of both the original (implied) author and the (implied) translator as producers of the translated discourse:

An implied translator organizes the way in which the translation's implied reader is informed about the original author's "message." Unlike an original narrative communication, we can say that the translated narrative communication has as a textual characteristic two addressers addressing one addressee. We can also say that when we read a translation as a translation we practically share both the set of presuppositions underlying the original narrative and the set of norms informing the translation. (Schiavi 1996: 17)

O'Sullivan (2006) applies the ideas of Hermans (1996) and Schiavi (1996) to the translation of children's literature specifically. Most of her paper is an unpacking and elucidation of these ideas, but in addition she also argues that the translator's voice is not only heard in the kind of largely paratextual interventions outlined by Hermans (1996), but can also be identified in "the voice of the narrator of the translation" (O'Sullivan 2006: 105). She argues that shifts in the voice of the narrator may be productively viewed as an index of the translator's voice in the text:

The discursive presence of the translator can be located in every translated narrative text on an abstract level as the implied translator of the translation. The translator's voice can make itself heard on a paratextual level as that of "the translator" and is inscribed in the narrative as what I have called "the voice of the narrator of the translation." (O’Sullivan 2006: 108)

As far as translated children's literature specifically is concerned, O'Sullivan (2006: 108) points out that the voice of the narrator of the translation is more evident or audible in children's literature, because of the asymmetrical communication situation involved in children's literature. Children's books are written by adults, for children (and also simultaneously for other adults; see section 2.2.). In this, adult perceptions of who and what children are, what they ought to be reading, and what 
they can read (in other words, adults' "child image") have a profound influence. This influence extends to translation too, where a translator's child image (based on her experience, cultural and temporal background) may be vastly different to that of the original author, resulting in the construction of a different implied reader of the translation, a different "implied author" (really the implied translator) and a different narrative voice (a narrator altered by the translator based on her perceptions of the child). Linguistic issues are obviously important in this regard, but also cultural and social issues, probably most saliently reflected in the tension between and interplay of source-text and target-text oriented translation strategies, which may also be cast, in the terms of Venuti $(1995,1998)$ as domesticating and foreignising strategies. This tension is a matter of particular concern in the translation of children's literature, with some scholars arguing that cultural adaptation and domestication are essential to ensure that the child reader is able to identify with the text, and others positing that over-zealous adaptation and domestication are at best a consequence of adults' possibly inaccurate preconceptions about what children can understand, and at worst a reflection of a lack of respect for other cultures and an attendant desire to reduce cultural difference to sameness (for some contributions on these issues, see Klingberg 1986; Nikolajeva 1996; Oittinen 2000, 2006; O'Sullivan 2005; Stolt 2006; Yamazaki 2002).

\subsection{Challenges to structuralist conceptions of narrative communication in translated (children's) literature}

There is a crucial shortcoming of the narratological model developed by Schiavi (1996) that becomes particularly evident when the model is used in the context of translated children's literature. Children's literature, as Richardson (2007: 259) points out, is the most obvious category of narrative that often includes works with two different audiences in mind: the child as well as the adult. In some instances, this dual audience may be particularly evident, even resulting in dual address (see Beckett 1999; O'Sullivan 2005 for some work on this issue). However, even in instances where a book does not explicitly depend on what Richardson (2007: 259) refers to as "two different prestructurings, one for the simple child and the other for the knowledgeable adult," children's books always to some degree "address" an adult reader - the adult is, after all, the person who selects and buys the book, and often reads it with the child. In this sense, the real adult writer is also always directing some of her discourse at the real adult reader-buyer, in addition to the real child reader. In the educational context, there are also additional adult audiences, such as teachers, librarians and officials in education departments in charge of book selection. The production and dissemination of children's books is therefore deeply imbricated in a "communication" between adults, based on adults' personal and social beliefs, values, ideologies and preconceptions about children, childhood and reading (see also Nodelman 2008).

This double audience of children's literature opens a hidden vein of difficulty for a model such as Schiavi's (1996). If children's literature is considered in terms of Schiavi's (1996) narratological model, it would mean that the real reader (of the original text) needs to be differentiated as at least two real readers, the child and the adult reader. This necessitates the distinction of two implied readers, and if one fol- 
lows Schiavi's (1996) logic which insists on the symmetry of narrative relationships (to a real author corresponds a real reader; to an implied author, an implied reader, etc.), also two implied authors. The multiplication of agents becomes even more pronounced when one brings translation into the equation. This means that there must then not only be a real adult reader and real child reader (and an implied adult reader and an implied child reader) of the original, but also of the translation. Correspondingly, there would need to be an implied author from the child reader's perspective and an implied author from the adult reader's perspective for both the original and the translation. Finally, the concept of the implied translator would also need to be divided into two entities: the implied translator as constructed by the child reader and the implied translator constructed by the adult reader of the translation.

However, I would argue that it is not only children's literature that poses the problem of multiple implied readers, though it is made most explicit in children's literature. Many literary texts address themselves to more than one implied reader, and sometimes these readers may be in conflict. As Richardson (2007: 261) points out, "the basic divisions in society (gender, race, class, and sexual orientation) regularly produce opposed readers, and these oppositions are regularly inscribed within texts." This observation destabilises the conceptual categories assumed as unproblematic by classical narratologists. Apart from this destablisation of conceptual categories, I also believe that the proliferating set of agents produced by this particular interface of narratology and translation studies is of limited value, predominantly because it does not focus on the reading experience itself, ${ }^{6}$ and the way in which readers construct the relationships within a text. It is also, I contend, an unnecessarily unwieldy way of talking about the effects of translation on narrative relationships. It may well be more productive to seek a different modulation of the interface that is more "user-friendly" and flexible, and also avoids the reductiveness that is often the consequence of structuralist approaches.

The two issues of the destabilisation of narratological concepts and the role of the reader warrant some further discussion here. As far as the first is concerned, it has already been pointed out that the structuralist narratological paradigm that informs most investigations of the effect of translation on narrative communication has generally remained unquestioned and unproblematised in such investigations. As a consequence, concepts such as the "implied author," "implied reader" and "narrator" have been used without interrogating them, despite the fact that the conceptual foundations of such concepts have been questioned by work in narratology and other fields. For example, Richardson $(1997,2006,2007)$ has argued for new models of narrative communication, particularly focusing on deconstructing the concept of the implied author and the implied reader as monolithic and singular entities. In particular, he argues that narrative theory will benefit from rejecting "models that insist, based on categories derived from linguistics or natural narrative, on firm distinctions, binary oppositions, fixed hierarchies, or impermeable categories" (Richardson 2006: 139). As already mentioned, Richardson (2007) points out numerous examples of how some texts are prestructured for multiple implied readers, some of whom may be in conflict. While Richardson (2007: 267) is at pains to point out that he believes the presence of multiple implied readers is comparatively rare, he does point out the obvious example of children's literature. He also focuses on issues of race, gender, and postcolonial writing, and additionally posits that some texts are written for two 
different implied readers in the same body: the first time-reader and the re-reader (Richardson 2007: 266).

Criticism of the concept of the "implied reader" has been coupled with similar criticism of the "implied author" (see Kindt and Müller 2006). The narrator, too, has come under fire. Arguing from a cognitivist-narratological paradigm, Fludernik $(1993,1996,2003 b)$ is critical of the essentialisation or personification of a narrator figure in texts without clear linguistic evidence (deictic or expressive markers) to suggest such a persona. She argues that "what we were observing in narratologists needing a narrator for A portrait of the artist as a young man was an illicit transfer of real-life frames of storytelling onto the communicational process of narrative and into the theoretical structures of narratology" (Fludernik 2003b: 262). Ryan (2001b) has deconstructed the concepts of both narrator and narratee, arguing that the mode of existence and visibility of the narratee is as variable as that of the narrator, which she reduces to three defining rather than descriptive functions (creative, transmissive and testimonial). Ultimately, Ryan (2001b) views the narrator as a theoretical fiction which may assume the guise of a human persona. Walsh (1997), too, calls into question the concept of the narrator as a distinct and essential agent of narrative.

In conceptualising narrative communication in translated children's literature, all the above issues need to be taken into consideration - which has not been the case in attempts to link translation studies and narratology so far. ${ }^{7}$

As far as the issue of the role of the reader is concerned, the existing narratology/ translation studies interface most often depends on comparative analysis of source and target text, with a view to identifying translation shifts in the linguistic-textualnarratological dimension. This comparative approach suggests a "scientific" or "critical" approach to the reading of translation - but completely discounts the actual natural reading process in which readers only engage with the target text, without ever accessing the source text. This is part of the overarching tendency of narratology to ignore the reader. Prince (2003: 11) has pointed out the absence of a focus on the reader in narratological approaches, but has also indicated that readers' responses to narrative features are an empirical problem requiring empirically derived answers. In what follows, an attempt is made to develop a double-barrelled narratological framework for translated (children's) literature that builds on the idea of comparative textual analysis, but also integrates the perspective or experience of the reader.

\section{Narratology and translation studies: towards a new paradigm}

In considering developments in narratology that may be useful in addressing the concerns outlined so far in this paper, two foci emerge as potentially meaningful. The first focus centres on the cultural or social dimension, and includes approaches such as cultural studies narratology and ideologically oriented narratological approaches (see Nünning 2003: 240). The second focus hinges on the relationship between the text and its readers, and includes contextualist narratology, cognitive narratology, psychonarratology and reader-response narratology. While both these foci have potentially useful contributions to make to a theoretical paradigm dealing with the translation of children's literature, only the latter will be pursued here, as most pertinent to the specific concerns raised in the previous section. A brief overview of some developments in the broad field of contextualist narratology, cognitive 
narratology, psychonarratology and reader-response narratology is first provided, followed by a more comprehensive elaboration of the specific framework for the analysis of narrative communication in translated children's literature proposed in this paper.

\subsection{Narratological approaches sensitive to the role of the reader}

Herman (2003: 6-11) focuses on three approaches to narrative: structuralist, contextualist and cognitive. He argues that while structuralist narratology forms the basis of further enquiry into narrative, contextualist and cognitive approaches to narrative address two important dimensions of structuralist narratology not adequately explored by structuralist approaches themselves. Contextualist approaches, in his view, constitute a means of investigating (narrative) parole "not as manifestations of a code that preexists all communicative acts, but rather as an interactional achievement, negotiated by participants using an inherently variable linguistic code in situated contexts" (Herman 2003: 7). The focus therefore falls on the interaction between participants in the narrative communication situation, including the reader. Cognitive approaches, Herman (2003: 9) argues, focus on (the narrative) la langue, the simultaneously cognitively and socially constituted system of narrative. In this project, the cognitive processes and responses of real readers are of paramount importance.

Contextualist approaches, according to Chatman (1990: 310) emphasise narrative as an act, as somebody telling someone that something happened, rather than as merely a structure: “... its whole emphasis is to show that the literary narrative... simply extends into the world of texts the same 'peer' relationship that exists between interlocutors in the ordinary speech situation" (Chatman 1990: 314). Correspondingly, contextualist approaches tend to place a great deal of emphasis on real authors and real readers, as opposed to a profileration of textual configurations such as the implied author, implied reader, narrator, narratee, and so on. These textual configurations are not necessarily denied, but their relative importance in the narrative communication process is reassessed by focusing on narrative as a communicative transaction that takes place in a particular social context as part of social behaviour. To elaborate this focus, contextualist narratological approaches draw heavily on sociolinguistics and speech-act theory, and particularly work on natural narratives (also called vernacular narratives or narratives of experience) and conversation by researchers such as William Labov and Joshua Waletsky, and Paul Grice (Chatman 1990: 314).

Chatman (1990), however, is generally sceptical of the contributions of such an approach, believing that the wide sociological focus of contextualist approaches does not yield much that enriches narratology as a field (Chatman 1990: 315). In particular he is critical of the focus on real authors and readers, arguing specifically that there is little insight into the peculiar qualities of narrative to be gained from readers' motives for reading and writers' motives for writing: "where in the welter of such motives shall we find information of significance for the study of narrative?" (Chatman 1990: 315). He also criticises the use of the natural narrative paradigm, claiming that it is too narrow, limited and unsophisticated a base, especially compared with the rich and wide-ranging base offered by literary narratives (Chatman 1990: 317). Ultimately, he argues that while there may well be validity to the claims 
of contextualist narratologists, theorists ought to be sceptical at least until some concrete proof is available (Chatman 1990: 316).

In the two decades since Chatman's (1990) article was published, contextualist approaches have been developed in more detail (in, for example, the work of Fludernik 1996, and Bortolussi and Dixon 2003). Herman (2003: 8) points out that the contextualist approach has had the important effect of emphasising the necessity of analysing both the structural features and the contextual functions of stories. Additionally, some work done in the field has also focused on the interactive and participative dimension of narrative and meaning-construction (Herman 2003: 8). While it is true that it may not be possible to transfer the insights into conversational narrative directly to literary narrative, the insights gained from contextualist approaches have an important role to play in the framework of narrative communication for translated children's literature proposed in this paper.

Firstly, children's literature constitutes a special instance of literature where an actual, physical communication situation, akin to conversation or natural narrative, may be involved. Of course, this is not always the case, but is frequently so for children's books as defined for the purposes of this paper. Many children's books are intended to be read aloud by an adult, to the child, or to be read collaboratively. In the case of picture books, the pictures are also in part intended as stimulus for conversation and elaboration. Readers used for educational purposes are similarly also often read aloud, and in conversational contexts in classrooms. In the case of children's literature, therefore, the interaction between real participants in the communication situation is demonstrably more important than in the case of narrative works for an adult audience. However, the conceptualisation of the communication process as taking place between an author and a reader needs some consideration and revision, especially if it is to be considered from the point of view of the child reader, and also if the impact of translation is to be accounted for. This matter is addressed in more detail in section 3.2. Secondly, the emphasis on structural features together with contextual functions is crucial for the argument in this paper, which aims to construct a framework that includes both dimensions. This aspect is likewise elaborated in the aforementioned section.

Together with contextualist approaches, the field of cognitive narratology has opened up new veins of enquiry within narratology that are particularly meaningful in the context of this paper. ${ }^{8}$ Herman outlines the field of cognitive narratology as follows:

As an interdisciplinary program for research... cognitive narratology blends concepts and methods from narratology with ideas originating from psychology, artificial intelligence, the philosophy of mind, and other approaches to issues of cognition. Work in this hybridized domain of inquiry seeks to construct a cognitive basis for - or motivation of - categories and principles developed by theorists concerned with narrative structure and narrative interpretation. (Herman 2003: 20)

Cognitive narratology, and the related field of reader-response narratology, results from the recognition of many narratologists that an understanding of narrative also requires an investigation of how narrative functions for readers (Bortolussi and Dixon 2003: 11). Some contributions in the field of cognitive narratology include work by Bortolussi and Dixon (2003), Fludernik (1993, 1996), Herman (2003), Jahn (1997), Rigney (1992) and Ryan (1991, 2001a). In some of this work, there is significant interaction between contextualist, structuralist and cognitive approaches, which 
Herman (2003) regards as the way forward for research in narrative. Fludernik (2003b: 243), for example, formulates her key concern in Towards a "natural" narratology (1996) as the formulation of a narratological paradigm based on conversational narrative (natural narrative in the terminology of Labov) and based on cognitivist parameters. In this, she moves in the direction of pragmatics, reception theory and constructivism (Fludernik 1996: xi). Bortolussi and Dixon (2003) similarly draw on reader-oriented literary studies, narratology, discourse processing and sociolinguistics, supplementing the gaps in each field by drawing on the others. ${ }^{9}$

Bortolussi and Dixon (2003) term their approach "psychonarratology," and describe it as an attempt "to establish vital links between literary studies (in particular, reader-response theory and narratology), cognitive psychology (in particular, discourse processing), and branches of linguistics" (Bortolussi and Dixon 2003: 4). This approach is based on an empirical research framework for studying reader response to narrative, since, in their view, a major shortcoming (amongst others) of work in reader-response approaches to literary studies is a lack of empirical validation and a reliance on intuitive, generalising, speculative and ultimately circular theories, arguments and suppositions about readers' responses to narrative texts (Bortolussi and Dixon 2003: 5-10). They believe that

[h] ow readers process narrative is essentially an empirical question that can only be answered by systematic observation of actual readers reading actual texts; it cannot be answered solely on the basis of intuition, anecdotal evidence, or even sophisticated models of human experience. (Bortolussi and Dixon 2003: 13)

However, they also believe that such empiricism needs to be theory-dependent, drawing most specifically on an interface between narratology and discourse processing (Bortolussi and Dixon 2003: 23-24).

The remainder of this paper draws on some of the ideas of Bortolussi and Dixon (2003) and adapts them to the study of translated children's texts, in an exploratory attempt to integrate the textual focus of most current narratology/translation studies interfaces into a framework that combines the textual, the contextual and the reader, and opens up new research questions and possibilities.

\subsection{The analysis of narrative communication in translated children's books: a new framework}

Bortolussi and Dixon (2003: 24-25) outline two key insights informing their work. The first is that the text-as-communication framework common in discourse processing research, which assumes that the text is a communication between author and reader, is not productive for the study of literary texts. Instead, they argue that readers treat their representation of the narrator as they would a representation of a conversational participant. They clarify:

...this view is distinct from the more common supposition that the reader communicates with the author via the text. In particular, we explicitly avoid any suggestion that the relationship between the [reader and] narrator can be described as communication in any real way. Indeed, because the narrator is not a real person, he or she cannot be said to have intentions or messages to communicate to the reader. Instead, our thesis is that readers process the narrator as if they were communicating with an individual in conversation. (Bortolussi and Dixon 2003: 30) 
The second insight is that it is essential to make a clear distinction between the features of the text, as constructed by the author, on the one hand, and the reader's mental constructions on the other (see also Ryan 2001a: 46). Bortolussi and Dixon (2003: 28) define a textual feature as an element of the text that can be objectively identified, such as narration style, speech style and aspects of characterisation. Reader constructions, on the other hand, are viewed as various types of mental constructions, changes in readers' attitudes or beliefs, and affective responses (Bortolussi and Dixon 2003: 28). By their nature, constructions are subjective, variable and contextdependent. However, they can be observed, empirically, by means of experiments carefully designed to investigate readers' responses to particular features.

The above distinction between features and constructions draws on contextual narratology's emphasis on the distinction between structure and act, and provides a useful way of conceptualising a double-pronged framework for a study of translated children's literature able to accommodate the interaction between texts and readers.

In the first instance, the framework proposes a textual dimension for the analysis of translated children's literature. The textual dimension focuses on narratological elements (like narration, characterisation and focalisation) analysed in terms of linguistic and discourse features, and is based on a comparative analysis of the source and target text. The aim of this is to identify translation shifts affecting the particular narratological elements. Such an analysis of translation shifts will most likely reveal the presence of the translator, and the nature of these shifts can be accounted for by the translator's variable and modulated selection of domesticating and foreignising translation strategies, which is influenced by her perception of the role and function of children's books, and of translation. This part of the framework therefore draws on the existing, largely structuralist approaches combining translation studies and narratology such as that of Schiavi (1996) and O'Sullivan (2006).

However, the second dimension of the proposed framework moves away from approaches like these, in positing that despite the fact that translation shifts effect changes in narrative features, and that there is therefore both an identifiable extratextual and intratextual translation presence in the text (traceable in paratextual comments and comparative readings of source and target texts), child and adult readers' responses to translated children's texts do not necessarily and by default incorporate an awareness of the presence of an additional "voice" in the text, that of the translator. At this point the framework departs from standard narratological models of translation in proposing the necessity of investigating reader constructions rather than textual features alone..$^{10}$

As far as the relationships of narrative communication are concerned, Bortolussi and Dixon (2003: 72) see the key communicative relationship in the text as existing between the real reader and the narrator. However, theirs is a very particular concept of the narrator: "Our fundamental departure from the earlier scholarship is to treat the narrator not as logical or abstract characteristic of the text but as mental representation in the mind of the reader. In other words, the narrator should be viewed as a reader construction." They go even further and hypothesise that the reader's representation of the narrator is analogous to the way in which one would construct a conversational participant, as already pointed out above. The hypothesis is based on "the intuition that communicative processing is central to the processing of narrative without being encumbered by the conceptual difficulties that an assumption 
of real communication entails" (Bortolussi and Dixon 2003: 72). They make clear that even though there is no real conversational communication, readers construct narrators as though they were conversational participants (Bortolussi and Dixon 2003: 73). The consequence, therefore, is that "[c]ommunication and the related assumptions of speech act theory only exist as processing strategies in the mind of the reader" (Bortolussi and Dixon 2003: 74).

This implies, firstly, that there are conversational processes at work. The reader attributes to the narrator those properties that are necessary for conversational communication (Bortolussi and Dixon 2003: 72). This includes shared perceptual ground, language and culture. Bortolussi and Dixon (2003: 72) cite experimental findings that suggest when this is not the case, readers have difficulty understanding and remembering material. In the context of the translation of children's books, this observation has a number of crucial implications, particularly in terms of the interplay between source-text and target-text oriented strategies. It suggests that in translation there must be a significant degree of domestication of the narrative function for readers to adequately engage with the narrative. This is not to suggest wholesale adaptation to the target culture and target readership's expectations, but it appears that some domestication is essential in order to ensure sufficient overlap between readers' cultural schemas and the text's cultural schemas to ensure effective and meaningful text processing. It may be hypothesised that this would be particularly important for children's books, due to the particular level of cognitive, social and cultural development of child readers.

Secondly, this approach implies that the reader assumes that the narrator is cooperative (in the sense encompassed by the conversational postulates of Grice 1975). This means that readers assume that the narrator will provide only necessary and sufficient information (the maxim of quantity), that the narrator will only say that which he/she believes to be true (the maxim of quality), that the narrator will say only that which is relevant (the maxim of relation), and that the narrator will be concise and avoid obscurity (the maxim of manner) (Bortolussi and Dixon 2003: 20). Readers thus process the textual features associated with narration according to these principles.

The principles of deictic shift theory may have some relevance here, since both Bortolussi and Dixon's (2003) approach and deictic shift theory presuppose a "breaking" of the conventional frames of narrative communication. While in traditional narrative communication approaches, communication can take place only between pairs of entities that exist on the same ontological level (e.g. real/real: author/reader, or textual/textual: narrator/narratee), both these approaches suggest a blurring of ontological boundaries. Bortolussi and Dixon (2003) argue that the actual communication of a literary text is effected by an interaction between the reader and the reader's representation of the narrator, based on textual signs. Deictic shift theory assumes that

in fictional narrative, readers and authors shift their deictic center from the real-world situation to an image of themselves at a location within the story world. This location is presented as a cognitive structure often containing the elements of a particular time and place within the fictional world, or even within the subjective space of a fictional character. (Segal 1995: 15) 
Based on this, one may formulate a conception of narrative communication that is even more radical than Bortolussi and Dixon's (2003) already radical (from the perspective of structuralist narratology) notion of how narrative communication works. It may well be argued that readers do not construct a narrator, as a distinct and personified entity, at all. This leads to an alternative proposal of what readers do, cognitively, with the textual features they encounter when reading a text. The question is whether readers really use these features primarily to construct a narrator regardless of whether this narrator is personified in the text or not - or whether they primarily use them to construct a fictional world from a particular perspective and with a particular degree of personal involvement which is determined by the narration but not necessarily dependent on the concept of a narrator. Returning to the idea of deictic shift, the essence of narrative communication may be regarded as the position from where the reader accesses the fictional world. In other words, the reader's access to and construction of the fictional world is determined by her processing of textual features associated with narrative communication, all of which serve to position the reader in a certain way in relation to the narrative. This is the idea explored by Kruger (2001, 2009), who proposes the concepts of impostulation and the narrative origo. He defines impostulation as follows: "Narrative impostulation can be defined as that aspect of narrative through which events, experiences, thoughts, dialogue, setting and characters are both imposed and postulated by the author and reader (and then also by the translator as author or rewriter and as reader)" (Kruger 2009: 19). In this process, an overt narrator need not be impostulated (though it may, as a narrative device). Instead, Kruger (2009: 19) suggests the concept of the narrative origo, which is an orientational position assumed by the author and reader in the impostulation. The narrative origo is "the deictic centre that is a vortex from which and through which and into which characters, events, settings, mental activity, perspective and narrative voice are impostulated both interpretively and presentationally..." (Kruger 2009: 19). In this process, the reader makes use of the linguistic markers of the text imposed by the author - there is thus "a demand... imposed on the reader to participate in the imaginary projection that is narrative" (Kruger 2009: 19).

At this juncture I should clarify that this argument does not serve to invalidate the concept of the narrator. Rather, it makes the double perspective offered by the distinction between features/constructions all the clearer. The features of a text are textual givens, fixed as produced by the author. However, the construction of the narrative world takes place in what the reader does, cognitively, with these features. This means that, certainly, it is possible for a narratologist as a particular kind of reader to construct these markers, collectively, as the textual instantiation of an entity or person telling the story. However, it may be just as possible for a different (type of) reader to use these features in a completely different process, not arriving at the same end result at all. In the same way a translation scholar, as a particular type of reader (specifically reading the source and target text comparatively), may construct the shifts in markers of narration (for example) as constituting the intratextual presence of the translator. A different (type of) reader will not necessarily construct these markers in the same way.

In the context of this paper, then, the pertinent question is how child readers (and adult readers) of translated children's books process the textual features associated with narrative communication, and, of course, whether shifts taking place in 
the translation process lead to a different processing outcome. Essentially, two questions arise from the above. The first is the more general question: Do children (and adults) process the textual features associated with narrative communication in a process that involves the construction of a narrator, or do they rather process these textual features as a means to access the fictional world and identify with a narrative perspective, without necessarily involving the construction of a narrator figure? The second question is more specific, and relates particularly to translation: Do the changes to these textual features that take place in translation (linked to domesticating and foreignising strategies) result in a different processing outcome (either a different narrator or a different fictional world) for child and adult readers of the original text and the translated text?

These are, obviously, empirical questions that require carefully constructed experimental designs to answer. Since this falls outside the scope of this paper, the following section will conclude with some hypotheses and speculations that may be useful for future research.

\section{In conclusion}

Firstly, as has already briefly been suggested, one might argue that since children most often (at least initially) encounter narratives in actual conversational situations where stories are physically told by someone, this might lay the foundations of a cognitive framework in which stories are processed as if they are narrated by someone, thus necessitating the cognitive construction of a narrator (this lends credibility to the argument of Bortolussi and Dixon 2003). In the case of translated texts, the shifts that take place in translation may therefore result in a different narrator construction, depending on the nature and degree or persistence of the shifts.

Secondly, however, one may argue that the cognitive abilities of young children are not developed to the degree that they process textual features to construct such a narrator - rather they process these features as a means by which to gain access to or "enter" or immerse themselves in the narrative world, without distinguishing an "agent" responsible for the construction of this world. In the case of translated texts, the shifts that take place in translation may therefore primarily result in the construction of a different world, since it is accessed differently. To supplement this, one might postulate that it is likely that adults, with a greater degree of cognitive sophistication and a more developed understanding of the relationship between the constructed reality of the narrative and the real world, will process these textual features in a different way, incorporating a narrator construction that is perceived as being responsible for the presentation of information in the text. If adult readers of translated texts are aware of the fact that they are reading a translation, they may be cognisant of the mediating effect of translation, and may thus also construct the textual presence of a translator. This awareness will most likely not be based on a comparative reading, but rather on a combination of paratextual references revealing the presence of the translator, and (more pertinently) oddities in the translation itself that may strike the adult reader as being the result of translation.

The above casts the possibilities in exclusive terms; however, a middle ground may be possible. A third possibility would be to argue that both child and adult readers (to varying degrees) process a text as if it were told by someone, but without 
necessarily constructing that someone as a personified entity (though this may be the case depending on the particular features of the individual text). A similar middle ground would thus obtain in translated texts.

The above possibilities suggest the potential of a narratological approach to translated children's literature that is based on the analysis of textual features as well as reader constructions. It allows investigations to move beyond comparisons of textual features of the source and target text, as well as structuralist interpretations of the narrative communication situation for translated children's literature focusing on a proliferation of intratextual agents of narrative communication. It opens various possibilities for exploring how readers actually process these features, and how the narrative communication situation actually functions for real readers. The latter is a matter for empirical scrutiny, utilising carefully constructed experimental designs (see Bortolussi and Dixon 2003). Such experimental designs may include, for example, the manipulation of the features of translated children's texts, and investigating child and adult readers' responses to these manipulated texts by using methods such as eye-tracking, comprehension testing and focus-group interviews exploring constructions of the narrator and the fictional world. It is hoped that the suggestions made in this paper will form the basis of productive further research combining analysis of the textual features of translated children's literature as well as the processing of these features by actual readers to arrive at a more nuanced understanding of how translation affects narrative communication.

\section{NOTES}

1. In this paper, "children's literature" is defined in a specific sense as fictional works, picturebooks and educational readers for young children, aged up to about ten years.

2. However, Prince (2003: 2) raises the point that it is by no means accepted by all that "the remarkable variety of discourses pertaining to narrative could or should be coherently subsumed by narratology" (a point also elaborated by Nünning 2003), and there are calls for narratology to be redefined in its narrower sense (see for example Meister 2003). Though this article takes cognisance of the debate (investigated in detail by Nünning 2003), it does not pursue it, but rather focuses on productive ways in which narratological concepts may be appropriated for the study of translated children's literature. As such, the distinction between "narratology" and "narrative theory" is also not argued (see Nünning 2003: 257-262), though this paper does rest on the assumption that narratology is a particular kind of narrative theory, distinguished by particular features and terminologies from other theories of narrative.

3. It should be noted that the authors are critical of such approaches, stating that contextualist narratological approaches do not adequately consider their own interpretive approaches or a general theory of interpretation (Kindt and Müller 2003: 207).

4. The implied author, in this understanding of the term, is a "textual artefact," "patterns in the text" or a "residue" (Schiavi 1996: 10) of the real author's work in organising and presenting the narrative text, including its connotations and the ideologies that inform it, as reconstructed by the reader. The implied author, however, is not the narrator - rather, the narrator is the voice in which the story is told, a storytelling tool or discourse element. The implied reader is the counterpart of the implied author, in other words the reader "presupposed" or inscribed by the narrative itself (see Chatman 1978: 150).

5. Reproduced from O'Sullivan (2006: 103). Permission for reproduction granted by the author.

6. In this context and for the purposes of this paper, it is important to note that for O'Sullivan (2006) gauging the inscribed presence of the translator in the voice of the narrator of the translation is dependent on a comparison between the source and target text (as also evident in the examples discussed by O'Sullivan 2006: 105-108). There are also general similarities in the contributions of May (1994) and O'Sullivan (2006), both of whom argue that translation results in changes to the narrator or narrative voice of the translated text, usually as a consequence of ideological factors that play a role in the translator's decisions. 
7. See also Bortolussi and Dixon (2003: 68-69) for other criticism of conceptualisations of various participants in the narrative communication situation.

8. Many of Chatman's (1990) concerns have been addressed by more recent research in both contextualist and cognitive narratology - often providing empirical substantiation for claims. See for example Bortolussi and Dixon (2003) and Herman (2003).

9. The work of Bortolussi and Dixon (2003) is clearly indebted to the work of Fludernik (1996), though they make clear that they believe her work to suffer from a tendency to "remain entrenched in vague generalities" (Bortolussi and Dixon 2003: 12) - a problem that they wish to rectify by means of their empirical approach.

10. In this, there is some similarity with the propositions made by Kruger $(2001,2009)$.

\section{REFERENCES}

BAL, Mieke (1990): The point of narratology. Poetics Today. 11(4):727-753.

Beckett, Sandra L., ed. (1999): Transcending Boundaries: Writing for a Dual Audience of Children and Adults. New York: Garland.

Bortolussi, Marisa and Dixon, Peter (2003): Psychonarratology: Foundations for the Empirical Study of Literary Response. Cambridge: Cambridge University Press.

Bosseaux, Charlotte (2004): Translating point of view: A corpus-based study. Language Matters. 35(1):259-274.

Bosseaux, Charlotte (2007): How Does it feel? Point of View in Translation: The Case of Virginia Woolf into French. Amsterdam: Rodopi.

Brooke-Rose, Christine (1990): Whatever happened to narratology? Poetics Today. 11(2):283293.

Снatman, Seymour (1978): Story and Discourse: Narrative Structure in Fiction and Film. Ithaca: Cornell University Press.

Сhatman, Seymour (1990): What can we learn from contextualist narratology? Poetics Today. 11(2):309-328.

Fludernik, Monika (1993): The Fictions of Language and the Languages of Fiction: The Linguistic Representation of Speech and Consciousness. London: Routledge.

FludERniK, Monika (1996): Towards a Natural Narratology. London: Routledge.

FluderniK, Monika (2003a): The diachronization of narratology. Narrative. 11(3):331-348.

FluderniK, Monika (2003b): Natural narratology and cognitive parameters. In: David Herman, ed. Narrative Theory and the Cognitive Sciences. Stanford: CISLI, 243-267.

Fludernik, Monika and Richardson, Brian (2000): Bibliography of recent works on narrative. Style. 34(2):319-328.

Genette, Gérard (1980): Narrative Discourse. Oxford: Basil Blackwell.

Genette, Gérard (1983): Nouveau discours du récit. Paris: Seuil.

Genette, Gérard (1990): Narrative Discourse Revisited. Ithaca: Cornell University Press.

Grice, H. Paul (1975): Logic and Conversation. In: John P. Kimball, Peter Cole and Jerry L. Morgan, eds. Syntax and Semantics: Speech Acts. New York: Academic Press, 41-58.

Herman, David (1999): Introduction: Narratologies. In: David Herman, ed. Narratologies: New Perspectives on Narrative Analysis. Columbus: Ohio State University Press, 1-30.

Herman, David (2003): Introduction. In: David Herman, ed. Narrative Theory and the Cognitive Sciences. Stanford: CSLI, 1-30.

Hermans, Theo (1996): The translator's voice in translated narrative. Target. 8(1):23-48.

JAHN, Manfred (1997): Frames, preferences, and the reading of third-person narratives: Towards a cognitive narratology. Poetics Today. 18(4):441-468.

KINDT, Tom and MüLLER, Hans-Harald (2003): Narrative theory and/or/as theory of interpretation. In: Tom KINDT and Hans-Harald MüLler, eds. What is Narratology? Questions and Answers Regarding the Status of a Theory. Berlin: Walter de Gruyter, 205-219.

KIndt, Tom and Müller, Hans-Harald (2006): The Implied Author: Concept and Controversy. Berlin: Walter de Gruyter. 
KLINGBeRG, Göte (1986): Children's Fiction in the Hands of the Translators. Lund: CWK Gleerup. KrUger, Jan-Louis (2001): Focalisation in the Translation/Rewriting of Narrative Texts: A.P. Brink's Imaginings of sand/Sandkastele. Doctoral thesis, unpublished. Potchefstroom: Potchefstroom University.

Kruger, Jan-Louis (2009): The Translation of Narrative Fiction: Impostulating the narrative origo. Perspectives: Studies in translatology. 17(1):15-32.

Levenston, Edward A. and Sonnenschein, Gabriela (1986): The translation of point of view in fictional narrative. In: Juliane House and Shoshana Blum-Kulka, eds. Interlingual and Intercultural Communication: Discourse and Cognition in Translation and Second-language Acquisition Studies. Tübingen: Narr, 40-59.

MAY, Rachel (1994): Where did the narrator go? Towards a grammar of translation. The Slavic and East European Journal. 38(1):33-46.

Meister, Jan Christoph (2003): Narratology as discipline: A case for conceptual fundamentalism. In: Tom Kindt and Hans-Harald Müller, eds. What is Narratology? Questions and Answers Regarding the Status of a Theory. Berlin: Walter de Gruyter, 55-71.

Nikolajeva, Maria (1996): Children's Literature Comes of Age: Toward a New Aesthetic. New York: Garland.

Nodelman, Perry (2008): The Hidden Adult: Defining Children's Literature. Baltimore: Johns Hopkins University Press.

NüNNING, Ansgar (2003): Narratology or narratologies? Taking stock of recent developments, critique and modest proposals for future usages of the term. In: Tom KindT and HansHarald MüLLER, eds. What is Narratology? Questions and Answers Regarding the Status of a Theory. Berlin: Walter de Gruyter, 239-275.

Oittinen, Riita (2000): Translating for Children. New York: Garland.

Oittinen, Riita (2006): No innocent act: On the ethics of translating for children. In: Jan van Coillie and Walter P. Verschueren, eds. Children's Literature in Translation: Challenges and strategies. Manchester: St. Jerome, 35-45.

O'Sullivan, Emer (2005): Comparative Children's Literature. London: Routledge.

O'Sullivan, Emer (2006): Narratology meets translation studies, or, the voice of the translator in children's literature. In: Gillian LATHeY, ed. The Translation of Children's Literature: A reader. Clevedon: Multilingual Matters, 98-109.

PrInCE, Gerald (2003): Surveying narratology. In: Tom Kindt and Hans-Harald Müller, eds. What is Narratology? Questions and Answers Regarding the Status of a Theory. Berlin: Walter de Gruyter, 2-16.

RichaRdSON, Brian (1997): The other reader's response: On multiple, divided, and oppositional audiences. Criticism. 39(1):31-53.

RICHARDSON, Brian (2000): Recent concepts of narrative and the narratives of narrative theory. Style. 34(2):168-175.

RICHARDSON, Brian (2006): Unnatural voices: Extreme narration in modern and contemporary fiction. Columbus: Ohio State University Press.

Richardson, Brian (2007): Singular text, multiple implied readers. Style. 41(3):259-274.

Rigney, Ann (1992): The point of stories: On narrative communication and its cognitive functions. Poetics Today. 13(2):263-283.

Ryan, Marie-Laure (1991): Possible Worlds, Artificial Intelligence, and Narrative Theory. Bloomington: Indiana University Press.

Ryan, Marie-Laure (2001a): Narrative as Virtual Reality: Immersion and interactivity in literature and electronic media. Baltimore: Johns Hopkins University Press.

Ryan, Marie-Laure (2001b): The narratorial functions: Breaking down a theoretical primitive. Narrative. 9(2):146-152.

Schiavi, Giuliana (1996): There is always a teller in a tale. Target. 8(1):1-21.

SEgAL, Erwin M. (1995): Narrative comprehension and the role of deictic shift theory. In: Judith F. Duchan, Gail A. Bruder and Lynne E. Hewitt, eds. Deixis in Narrative: A Cognitive Science Perspective. Hillsdale: Lawrence Erlbaum, 3-17. 
SтоLт, Birgit (2006): How Emil becomes Michel: On the translation of children's books. In: Gillian LATHey, ed. The Translation of Children's Literature: A Reader. Clevedon: Multilingual Matters, 67-83.

Van Leuven-Zwart, Kitty (1989): Translation and original: Similarities and dissimilarities I. Target. 1(2):151-181.

VAn Leuven-Zwart, Kitty (1990): Translation and original: Similarities and dissimilarities II. Target. 2(1):69-95.

Venuti, Lawrence (1995): The Translator's Invisibility: A history of translation. London: Routledge.

VenUti, Lawrence (1998): The scandals of translation: Towards an ethics of difference. London: Routledge.

WALSh, Richard (1997): Who is the narrator? Poetics Today. 18(4):495-513.

YAMAZAKI, Akiko (2002): Why change names? On the translation of children's books. Children's Literature in Education. 33(1):53-62. 